\title{
Cost Efficiency in Precast Construction Method on Multi-Storey Buildings
}

\author{
Dwi Dinariana and Dedy Wijaya
}

\begin{abstract}
Construction of buildings always spend substantial funds because of high construction costs and so we need a way to save on construction costs without lowering the specifications of the building itself. The study was conducted to determine the efficiency of the construction cost using precast method to the conventional method. It is intended that funds are available to build more buildings. The calculation of the cost of construction of precast units refer to SNI 9832-2012 (SNI 9832-2012, "Calculation Procedure Unit Price Work Precast Concrete Building Construction"). In this study, which reviewed the building is 3-10 storey building in Jakarta and Papua. Which large computation efficiency in terms of both structural components with foundation and without foundation. Based on calculations using precast method is then compared with the results obtained by the conventional method that precast method can reduce the cost of construction and the method of precast become more efficient. In Jakarta and Papua without foundation structure results obtained cost efficiency in 3-10 buildings storey of $7.6 \%-19.8 \%$. And with foundation structure results obtained cost efficiency in buildings 3-10 storey buildings of $4.7 \%-15.05 \%$.
\end{abstract}

Index Terms—Precast, construction, cost efficiency, building.

\section{INTRODUCTION}

Along with the increase in population is rapidly increasing and the limited amount of land, the demand for housing such as apartments / flats, and a center of economic activity or office to support a variety of people's lives is increasing.

Buildings are usually built with conventional methods where all necessary construction materials printed in a construction project, such as concrete columns and beams were cast directly on the project. There are a few things that concern in conventional methods, namely the long construction time and less clean, Quality control is difficult to be improved, as well as the basic material of formwork is increasingly expensive and scarce construction costs become more expensive. Today began the construction of many buildings using precast method. Precast system is a system development fabricated building components / printed first in the factory or in the field, then arranged on the ground to form a unity building. The advantages of this system include quality precast well preserved, the time of the construction of a relatively short, environmentally friendly, and less residual materials that must be removed out of the construction. Using precast method, then you could save a lot of costs such as for example the cost of formwork / formwork less ( \pm 12 times)

Manuscript received April 16, 2014; revised June 20, 2014.

The authors are with University of Persada Indonesia YAI Jakarta, Indonesia (e-mail dwidinariana@yahoo.com).
[1], and cost less because overheat faster execution time than conventional, so it becomes more efficient precast method compared to conventional methods. However, the efficiency of each building is different, it depends on the level of the building. In addition to the method is determined by the efficiency of a building is also determined from the prices of materials and wages. Material prices and wages vary by region, which may influence the efficiency of the buildings in the area.

In Indonesia, the precast method is also well known, the components - which are structural components using precast systems, including poles, columns, beams, and plate. In this research will discuss about the efficiency of precast construction, which will be compared between the conventional method and the method in terms of cost efficiency precast construction multi-storey buildings (3, 6, and 10 storey), then the comparison will be made if the building is being built in Jakarta and Papua . From the results of this comparison can be seen the efficiency of each region when using precast or conventional methods for the construction of multi-storey buildings.

\section{RESEARCH OBJECTIVES}

The purpose of this study is:

1) Calculate how much the building cost efficiency between precast methods and conventional methods in Jakarta and Papua on multi-storey buildings.

2) Determine patterns of cost-efficiency building from precast and conventional construction method in Jakarta and Papua on multi-storey buildings.

3) Analyzing the efficiency of the Jakarta and Papua on multi-storey buildings.

\section{LITERATURE REVIEW}

\section{A. Implementation of Construction Methods}

The basic functions of project management consist of managing scope, time, cost, and quality. In the management of a construction project, in order to obtain optimal results it is necessary methods of construction are in accordance with the construction project. In the construction of multistory building methods that can be used to achieve optimal results, in this study will be discussed on precast methods and conventional methods are often used in the construction.

\section{B. Method of Precast}

Precast system is a system of building components fabricated construction/first produced in a factory or in site, and installed at the site to be a unity building. Because 
production of these components are performed at the factory or in site, it can simplify the production process, and the precast components are given sufficient time so as to achieve the compressive strength hardening plans before installation. So precast components installed as a component that is so, so to be a building, these components will be assembled with other components. Because this method is done at the factory or in situ, the quality of the structural components can be well preserved, but the precast method can be used if the number of components typical of a construction reaches a certain minimum.
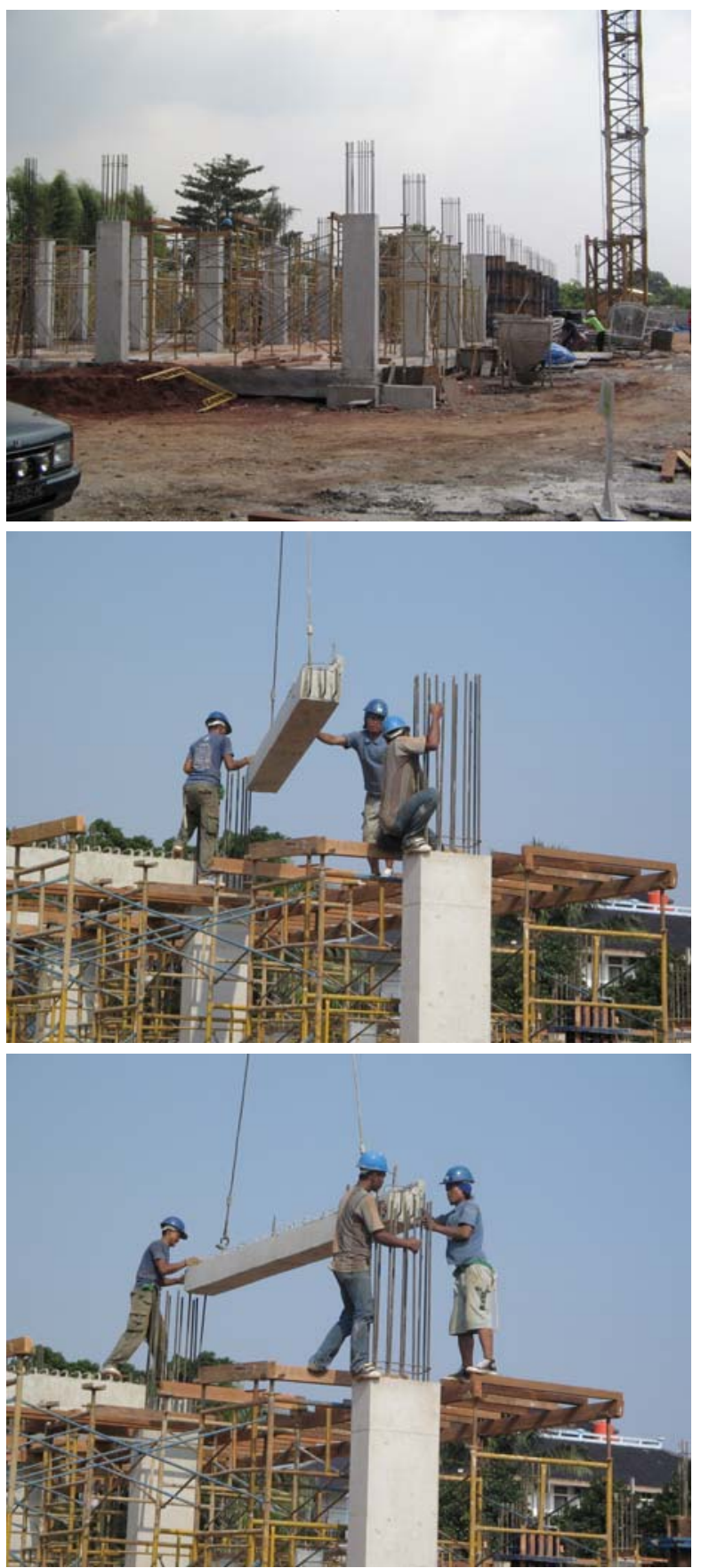

Fig. 1. Erection process the precast system.

The advantages of precast systems than conventional systems are [2]:

\section{1) This system allows the quality control is good}

The method for the production of precast in the factory, the precast concrete components becomes easier to do so results can be measured with good production.

The method of precast has thought about installation method so that it becomes easier installation components that guarantee the quality of the structures in building construction.

\section{2) Implementation shorter}

With the precast method precast components can be directly produced in conjunction with the implementation of the structure.

Because it does not require the installation of precast components scaffold the structure at the time of execution of the above, the underlying structure is able to do the finishing work of architecture.

\section{3) Environmentally friendly}

The use of wood as a mold can be reduced to a minimum. Less waste material

\section{4) More economical costs}

With better quality control then the value of the safety factor can be reduced to be more efficient.

The use of molds and scaffolding can be reduced thereby saving material for molds.

\section{Methods of Conventional}

In conventional methods of all components of the building is casted on the ground or in the project, this method is the method most commonly used in construction projects.

\section{Precast Systems in Indonesia}

Various advantages possessed by the use of precast concrete made very rapid progress. It makes all parties involved in the construction Indonesian world trying to find and develop an application system in a wide variety of precast concrete.

Full precast structural systems were developed in Indonesia since the construction of building flats sarijadi, Bandung in 1979, using Brecast system, but the new system is implemented en masse in 1955, on construction of flats Cengkareng by Waffle Crete Systems. Precast system is growing since then, which is marked by the emergence of many new systems, both from within and outside the country with his trademark respectively.

Since 1955, the Association of Precast and Prestressed Indonesia (IAPPI) already requires several processes that must be met before a system is recommended for use:

1) Precast system planning; componentization, connections, and methods of implementation.

2) Testing and modeling to determine the intrinsic nature of precast system

3) Seminar for dissemination, discussion and feedback for improvement

4) Making mock-ups

Fittings such as certificates and patents is a necessary but not absolute. There are several full precast systems which are actively used, and have gone through this process. The process of planning and control are things that can not be separated on a construction.

\section{E. Budget Plan of Conventional Concrete}

In preparing the budget plan in conventional, budget plan 
which is calculated based on the volume of each type of work multiplied by the unit price of each job, and calculated for all types of work on the project. So obtained the total of the budget plan for the construction [3].

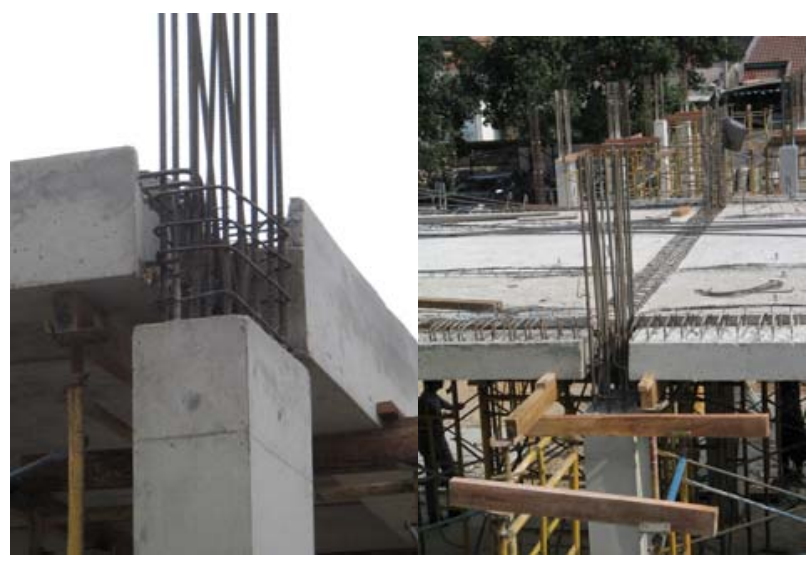

Fig. 2. Joint on the beam (the precast system).

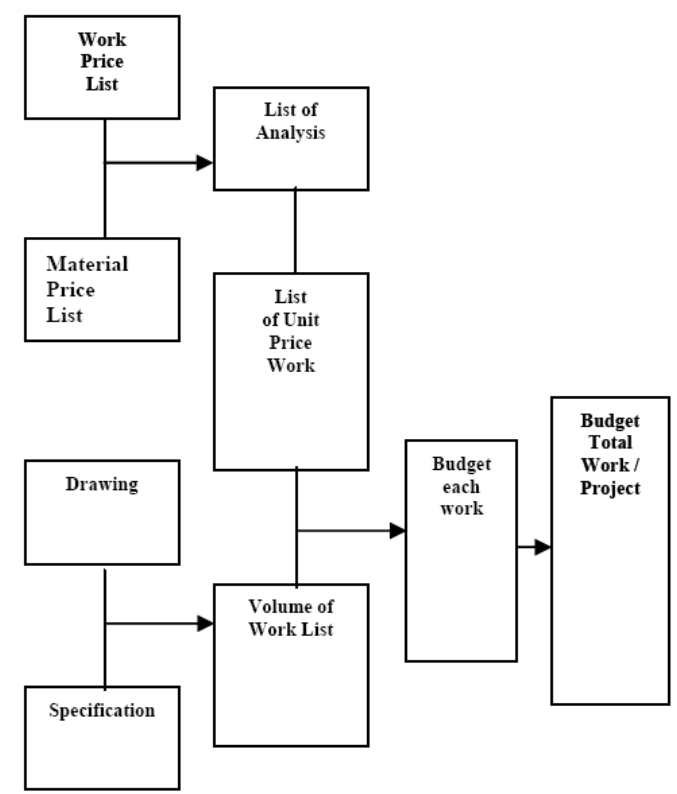

Fig. 3. Chart budget calculations of conventional concrete [4].

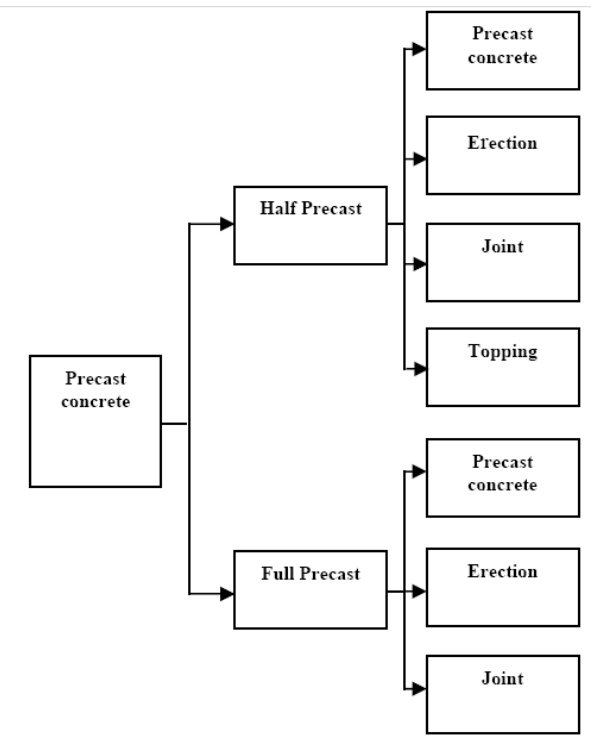

Fig. 4. Chart budget calculations of precast concrete [6].

\section{F. Budget Plan of Precast Concrete}

Budget plan in conventional concrete similar to precast concrete budget plan, due to the precast concrete is done at the factory so there is a difference in the project activities undertaken, and the coefficients used [5].

\section{RESULTS AND DISCUSSION}

\section{A. Region Jakarta}

Jakarta is located just north of the island of Java, at the mouth of the Ciliwung River, Jakarta Bay. Jakarta has an area of $\pm 650 \mathrm{~km} 2$ including mainland Thousand Islands, which are geographically located between $106^{0} 22^{\prime} 42^{\prime \prime}$ BT to $106^{0} 58^{\prime} 18^{\prime \prime}$ BT and $-5^{0} 19^{\prime} 12^{\prime \prime}$ LS to $-6^{0} 23^{\prime} 54^{\prime \prime}$ LS.

\section{B. Region Supiori (Papua)}

Supiori District is one district in the province of Papua, which has an area of $704.24 \mathrm{~km}^{2}$, which is divided into five districts namely South Supiori District, District Aruri, North Supiori District, District Supiori Western and Eastern District Supiori. Supiori District is located on the island Supiori separated by a strait Sorendiweri Biak Island. Located in the district capital Supiori Sorendiweri. Geographically located in the district Supiori $134^{\circ} 47^{\prime}$ BT to $136^{\circ} 48^{\prime}$ BT and $0^{0} 55^{\prime}$ LS to $1^{0} 31 \mathrm{LS}$.

C. Construction Cost Efficiency at Structural Work With Foundation and Structural Work Without Foundation in Jakarta

From Fig. 5, it can be seen that in the Jakarta area with the cost of without foundation increase the percentage value of cost efficiency and also changes the pattern of the efficiency of the 6 storey building as the lowest point in the structure calculations with foundation of $12.67 \%$ to 6 storey building as the highest point in the calculation of the structure without foundation by $19.8 \%$.

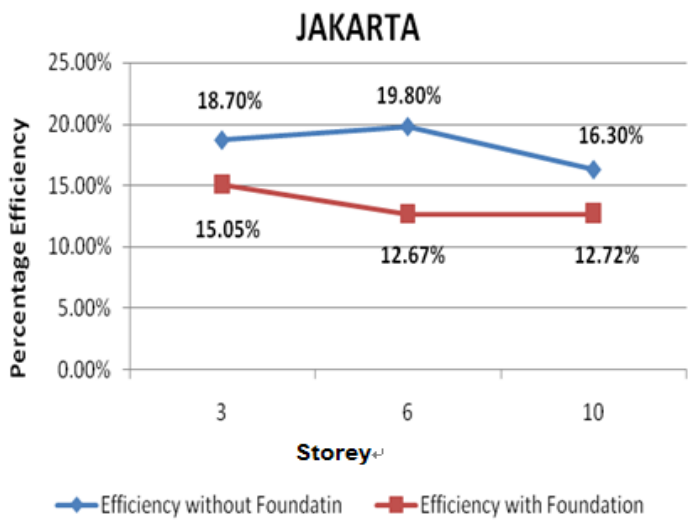

Fig. 5. Percentage efficiency at work structural with foundation and work structural without foundations in Jakarta.

D. Construction Cost Efficiency at Structural Work with Foundation and Structural Work WITHOUT Foundation in Papua/Supiori

From Fig. 6, it can be seen that in the region Papua/Supiori, without cost foundation increased the percentage efficiency value but no changes in the pattern of efficiency, which is the highest efficiency in the building 10 storey and the lowest is on 6 storey building. 


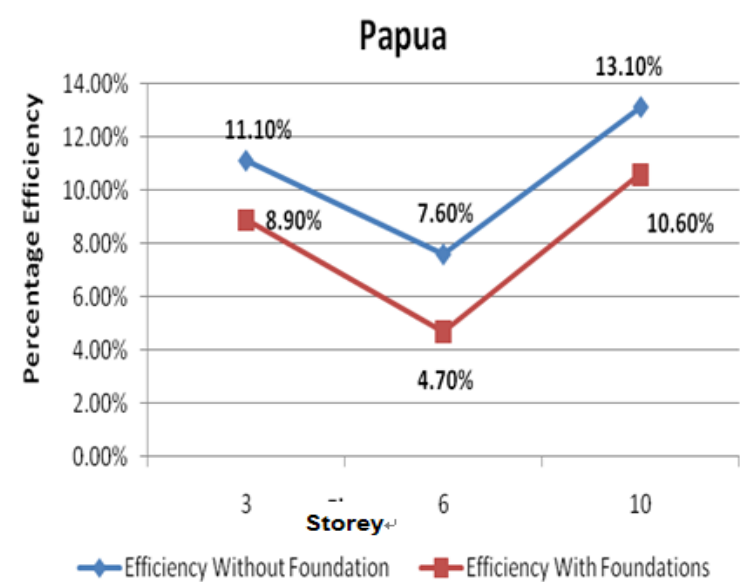

Fig. 6. Percent efficiency at work structural with foundation and work structural without foundations in Papua/Supiori.

\section{CONCLUSION}

In Jakarta, the percentage efficiency value precast method to conventional methods in 3-10 storey building $12,67 \%$ $15.05 \%$ (efficiency with foundation) and 16,30\% - 18,7\% (efficiency without foundation). From the results obtained that the percentage of efficiency construction costs with the foundation the highest are in the 3 storey building, while the lowest are in the 6 storey building. But the percentage of construction cost efficiency without foundation highest is at the 6 storey building, while the lowest are in the 10 storey building.

In Supiori region, the percentage efficiency value precast method to conventional methods in 3-10 storey building $4,7 \%-10.6 \%$ (efficiency with foundation) and 7,6\% - 13,1\% (efficiency without foundation). From the results obtained that the percentage of efficiency construction costs with the foundation and without foundation, the highest are in the 10 storey building, while the lowest are in the 6 storey building.

In Jakarta and Supiori (Papua) pattern efficiency is not proportional to the increase in the number of storey.

In Jakarta, the lowest efficiency values are on the 6 storey building, there followed a large increase in the lower building of the 6-storey building, but a small increase in buildings taller than 6-storey building. In Supiori region, the lowest efficiency values are on the 6 storey buildings, and then experienced a large increase in the lower building of the 6 storey building and again experienced a large increase in buildings taller than 6-storey building. In Jakarta region the efficiency is only a slight increase due to the increasing level of the building to the 10 storey building, while the region Supiori value has increased the efficiency along with increased levels of the 10 storey building.

\section{REFERENCES}

[1] SNI 7832-2012, The Procedure for the Calculation of Unit Price for the Precast Concrete Building (Tata Cara Perhitungan Harga Satuan Pekerjaan Beton Pracetak Untuk Konstruksi Bangunan Gedung), Badan Standarisasi Nasional (BSN), Jakarta, Indonesia, pp. 5-6, 2012.

[2] D. Dinariana, Analysis Unit Price Work Precast Concrete Building Structures (Analisa Harga Satuan Pekerjaan Struktur Beton Pracetak Bangunan Gedungt), 1st ed. Jakarta, Indonesia, pp. 3-4, 2013.

[3] I. Soeharto, Project Management: From Conceptual to Operational (Manajemen Proyek: Dari Konseptual Sampai Operasional), Erlangga, Jakarta, 1997.

[4] J. A. Mukomoko, Budgeting Basics Building Costs (Dasar Penyusunan Anggaran Biaya Bangunan), Gaya Media Pratama, Jakarta, 1985.

[5] D. Dinariana, Analysis Unit Price Work Precast Concrete Building Structures (Analisa Harga Satuan Pekerjaan Struktur Beton Pracetak Bangunan Gedungt), 1st ed. Jakarta, Indonesia, pp. 5-6, 2013.

[6] D. Dinariana, Analysis Unit Price Work Precast Concrete Building Structures (Analisa Harga Satuan Pekerjaan Struktur Beton Pracetak Bangunan Gedungt), 1st ed. Jakarta, Indonesia, pp. 5, 2013.

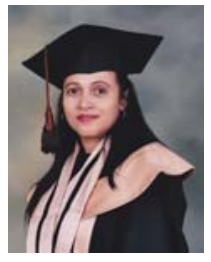

Dwi Dinariana was born in Madiun, Indonesia on July 5 1969. She got her B.tech degree in civil engineering from University of Sebelas Maret (UNS) Solo, Indonesia (1993). She earned her master of civil engineering from University of Indonesia (UI) Jakarta, Indonesia (2001). And then, she earned her Dr. degree in environmental and natural resources management from Bogor Agricultural University (IPB) at Bogor, Indonesia in 2011. Her research areas include construction and project management.

She is a lecturer and the head of Master Civil Engineering Programmes at the Faculty of Engineering, University of Persada Indonesia YAI

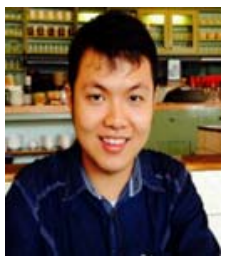

Dedy Wijaya was born in Ujung Pandang, Indonesia on June 24, 1990. He got his B.Tech degree in civil engineering from University of Bina Nusantara (Binus) at Jakarta, Indonesia in 2012. His research areas include construction and project management. 